\title{
GERENCIAMENTO DAS PLATAFORMAS ECOSSISTÊMICAS
}

\author{
AUTOR: ROBERTA GONCALVES DE OLIVEIRA MATOS \\ CO-AUTOR/ORIENTADOR: GILSON VIEIRA MONTEIRO
}

Resumo: "As Mídias Digitais como plataformas ecossistêmicas de comunicação" é um Projeto de Pesquisa, Desenvolvimento Tecnológico e Extensão Inovadora que teve como base os pressupostos teóricos da epistemologia ecossistêmica, que estuda as interconexões e o espalhamento das mensagens por meio das Mídias Digitais com o uso de plataformas ecossistêmicas de comunicação (receptoras e distribuidoras as duas coisas ao mesmo tempo) tais como WhatsApp, Twitter, Facebook, Instagram, YouTube, Podcast e similares. O que se fez foi pesquisar Sistemas Complexos, Dependência Digital, Letramento Digital, Linguagens e expressões humanas, ecologia dos saberes, tendo a interdisciplinaridade como suporte basilar e teorias que sustente a multidisciplinaridade, a interdisciplinaridade e a transdisciplinaridade como prática. Assim, trabalhou-se com a difusão e recepção de mensagens por intermédio de um meio convencional, o Rádio, através do quadro "Universidade e Você", na Rádio Sucesso FM, 104,9, do Grupo ECOEM (Grupo de Estudos e Pesquisas em Ecossistemas Comunicacionais e as Tecnologias da Inteligência), em "O Grande Jornal", que vai ao ar todas as quintas-feiras das $12 \mathrm{~h}$ às $13 \mathrm{~h}$, e suas interconexões com as Mídias como plataformas ecossistêmicas de comunicação. Essas atividades são a base para a divulgação das demais notícias propostas no Projeto de Pesquisa. Assim, poderá funcionar como um verdadeiro ecossistema informacional (e científico) conforme defendido por Davenport (1998), composto por ciclos (fluxos), canais (fontes), consumidores, gestores, armazenamento, enfim, por um universo de interações que envolvem os saberes internos e externos aos "Ambientes Comunicacionais Midiáticos" e "Processos informacionais científicos" das instituições de Educação Superior da Região. Deve ser capaz, também, de gerar um ambiente para criação de novos conhecimentos combinados com a difusão dos resultados das pesquisas e atividades de extensão, bem como notícias atualizadas na Mídias Digitais disponíveis.

PALAVRA-CHAVE: epistemologia ecossistêmica, ecossistemas comunicacionais, Mídias Digitais, interdisciplinaridade. 